\title{
Despirited Forests, Deforested Landscapes: The Historical Loss of Irish Woodlands
}

\section{Marjan Shokouhi}

\section{(2) OpenEdition \\ 1 Journals}

\section{Electronic version}

URL: https://journals.openedition.org/etudesirlandaises/6812

DOI: 10.4000/etudesirlandaises.6812

ISSN: 2259-8863

\section{Publisher}

Presses universitaires de Caen

\section{Printed version}

Date of publication: 14 November 2019

Number of pages: 17-30

ISBN: 978-2-84133-945-7

ISSN: 0183-973X

\section{Electronic reference}

Marjan Shokouhi, "Despirited Forests, Deforested Landscapes: The Historical Loss of Irish Woodlands", Études irlandaises [Online], 44-1 | 2019, Online since 14 November 2019, connection on 14 November 2022. URL: http://journals.openedition.org/etudesirlandaises/6812 ; DOI: https://doi.org/10.4000/ etudesirlandaises.6812

\section{cc) (ㅇำ}

Creative Commons - Attribution-NonCommercial-ShareAlike 4.0 International - CC BY-NC-SA 4.0

https://creativecommons.org/licenses/by-nc-sa/4.0/ 


\title{
Despirited Forests, Deforested Landscapes: The Historical Loss of Irish Woodlands
}

\begin{abstract}
This paper studies the history of deforestation in Ireland under the impact of consequent arrivals and departures, among which the advent of Christianity and the AngloNorman colonisation left a permanent mark on both the Irish landscape and culture. The aim is to understand how the island of Ireland, once known for its dense woodlands, became almost entirely denuded of tree cover by the end of the $19^{\text {th }}$ century and continues to be among the least forested regions in Europe. The history of deforestation in Ireland is an example of how environmental phenomena are closely linked with wider cultural and political concerns that characterise a certain period of history. Deforestation in Ireland was part of the colonial narrative that focused on subjugating the native population by taming the very landscape upon which they depended as a dwelling place.
\end{abstract}

Keywords: deforestation, Irish landscape, colonisation, Christianity, dwelling.

Résumé: Cet article traite de l'histoire de la déforestation en Irlande, au travers des flux migratoires consécutifs, parmi lesquels l'avènement du christianisme et la colonisation anglonormande, qui ont laissé une marque permanente à la fois sur la culture et le paysage irlandais. Il vise à comprendre comment l'île d'Irlande, autrefois connue pour ses denses régions boisées, est devenue presque entièrement dénuée de couverture forestière à la fin du XIXe siècle et reste encore l'une des régions les moins boisées d'Europe. Cette histoire de la déforestation en Irlande est un exemple du lien étroit entre les phénomènes environnementaux et de plus larges préoccupations culturelles et politiques qui caractérisent une certaine période historique. La déforestation en Irlande participe du discours colonial qui s'évertua à asservir la population locale en domestiquant précisément le paysage dont elle dépendait pour son habitation.

Mots clés: déforestation, paysage irlandais, colonisation, christianisme, habitation.

\section{Introduction}

Once considered one of the most heavily-forested regions in Europe, the Republic of Ireland lies at the bottom of the European forest cover index with less than $11 \%$ of its total land area under forest cover. Northern Ireland, with about $7 \%$ coverage, is often included with the rest of the United Kingdom with 13\% forest cover". Yet as the commemorative epithets of "The Isle of Wood" and "Emerald

1. Food and Agriculture Organization of the United Nations, Global Forest Resources Assessment 2015, $2^{\text {nd }}$ ed., Rome, FAO, 2016, available at: http://www.fao.org/3/a-i4808e.pdf, p. 5, 8. 
Green" imply, the memory of Ireland as a country densely covered in woodlands persists in Irish place names that owe their existence to the once significant relationship between people and trees in ancient Ireland. Derry, for example, is taken from Doire, signifying an oak grove. The prefix "Kill / Kil / Cill", common in Irish place names such as Kilcommon, Kildare, Kilkenny, derives from the Irish word Coill, which means a wood. MacCuill, son of hazel, MacCairthin, son of rowan, MacIbair, son of yew, and MacCuilin, son of holly, are also examples of Irish names related to trees.

Trees are interpreted as “charismatic' mega flora and fauna" ${ }^{2}$, which play an important role in invoking feelings of geopiety among environmental and regional groups. Coined by J. K. Wright in 1947, geopiety denotes "the sense of piety felt by humans in relation to both the natural world and the geographical space" ${ }^{3}$. In Ireland, feelings of geopiety as well as regional and national identity have often evolved around trees like oak, hazel, holly, and ash, which carry strong cultural implications. In Celtic cultures, "Every tree, mountain, rock and spring possessed its own spirit or numen" which had the power to "both foster and destroy living things" ${ }^{4}$. Trees were venerated by Irish Celts as a source of spirituality and power ${ }^{5}$. Along with herbs, they were used as medicine or associated with keeping off bad spirits or bringing good luck. Also included in the ancient Brehon laws, trees were considered communal property and cutting or mutilating them was a serious offence.

Taking into consideration this early culture of tree veneration, it is worth asking how the island of Ireland became almost entirely denuded of tree cover by the end of the $19^{\text {th }}$ century and now lies at the bottom of the European forest cover index. This essay addresses the cultural implications of deforestation in Ireland as a narrative that unveils the story of consequent arrivals and departures in the island of Ireland with an emphasis on two major events in Irish history: the Anglo-Norman colonisation of Ireland since the $12^{\text {th }}$ century and the advent of Christianity in the $6^{\text {th }}$ century $\mathrm{AD}$.

\section{A timeline of arrivals and departures}

The interaction of man and woodlands in Ireland is believed to have begun with the arrival of Mesolithic people, who were primarily fishers, hunters, and gatherers. Timber was used to make boats and houses. The settlement of Neolithic farmers

2. Carl J. Griffin, "Space and Place - Popular Perceptions of Forests", in New Perspectives on People and Forests, Eva Ritter, Dainis Dauksta (eds.), Dordrecht - Heidelberg - London - New York, Springer, 2011, p. 143.

3. Ibid.

4. Miranda Green, Animals in Celtic Life and Myth, London - New York, Routledge, 1992, p. 1-2.

5. See Charles Squire, Celtic Myth and Legend: Poetry and Romance, London, Gresham Publishing Company, 1905; Miranda Green, Animals in Celtic Life and Myth; Eoin Neeson, "Woodland in History and Culture", in Nature in Ireland: A Scientific and Cultural History, John Wilson Foster, Helena C. G. Chesney (eds.), Dublin, Lilliput Press, 1997, p. 133-156. 
around five to six thousand years ago and the development of the blanket bog resulted in the earliest clearance of forests, which mostly affected the West and Midlands.

The next group of settlers were the Celtic tribes who arrived in Ireland around 800 BC. The Irish Celts started a new phase of interaction with the wooded environment, commonly known as "tree veneration". Hazel meant wisdom; ash, yew, and oak were considered as sacred, and birch was associated with love. Trees were included in the ancient legal code of Ireland, known as the Brehon laws. According to their size, use, and fruit type, tree species stood for social order. In contrast to Norman Forest Laws which gave absolute ownership to an individual, the woodland laws in the Irish legal system were part of the common laws, where one piece of land with its natural resources was allocated to an individual of a high rank in trust, to be transferred to the next patron, who was not necessarily a direct inheritor. Communal ownership gave way to the rise of feudalism after the Norman Conquest in 1161. Medieval ownership, the development of the blanket bog, and farming resulted in what could be regarded as the first major period of deforestation in Ireland during the $12^{\text {th }}$ and $13^{\text {th }}$ centuries.

The felling of the forests and the change of land use accelerated in the $16^{\text {th }}$ century when Ireland officially became a British colony. The industrial development of the fuel-hungry British Isle, the growing demand for cheap timber used for shipbuilding purposes, and the inefficient and corrupt system of forest administration in Tudor England put the pressure on Ireland as a suitable target for invasion, both strategically and economically. The vast clearance of forests for agricultural purposes continued during the plantation period. "[S]ystematic plantation on a vast scale" from 1556 to 1690, by the English, Welsh, and Scottish landlords, conquered and subdued the inhabitants whose defence capabilities were dependent on forests as shelter and ambush ${ }^{6}$. The $17^{\text {th }}$-century plantation, which had started in the southern Midlands, spread through the entire country, leaving 1.5 million out of 2 million acres of Irish landscape under plantation ${ }^{7}$.

After the Tudors, deforestation continued during the Stuart and Commonwealth periods, decreasing wildlife biodiversity and gradually alienating the Irish, who had earlier relied on the woods as shelter, dwelling, and source of livelihood. In less than a hundred years the social and environmental effects of deforestation were already visible in Ireland. Native species such as wolves, eagles, birds of prey, and wild cats had dwindled as a result of losing their natural habitats. The Irish people, on the other hand, underwent immense pressure from the British colonisers who had not only bereft them of their shelter and source of income, but also gradually alienated them from their own dwellings in proximity of the woods. This was worsened in the aftermath of the Act of Union (1800) and the consequences of absentee landlordism,

6. Eoin Neeson, "Woodland in History and Culture", p. 140-141.

7. "History of Forestry in Ireland", Forest Service, Department of Agriculture, Food, and the Marine website, 2008. 
which severely affected the countryside, already hit by the increasing demand for food and shelter as a result of population growth from 1700 to 1840.

Nature, which had remained a source of livelihood and spirituality for centuries, had gradually become an awe-inspiring, threatening presence. The shift in attitudes is apparent in the reaction to the early reforestation schemes that planned to improve the rapidly dwindling Irish forests in the $18^{\text {th }}$ century. Reforestation started in 1765, at the hands of the gentry who were direct descendants of the planters. The schemes were "insufficient" and "clearly elitist" 8 , not paying the least attention to the local population and the negative impact of colonisation in poor rural areas. The Irish, who already regarded landowners as "'foreigners' and 'grabbers"' " , became more hostile towards both the owners and the land. The continuing hostility persisted for well over a century in the shape of mutilating and cutting trees as a sign of political protest. The reforestation scheme continued until 1845, regardless of the famine-stricken farmers who were denied all source of income during the minor periods of famine in the $19^{\text {th }}$ century. Ultimately an Gorta Mór, the Great Irish Famine that resulted in the death of more than one million people and the emigration of another million from 1845 to 1852, proved the indifference of the formerly "benign" nature to the suffering of millions of poor farmers whose only means of survival was the land.

The last but not least major cause of deforestation after the Great Famine was the Land Act of 1881, implemented for the purpose of transferring land ownership to farmers. Bereft of their major source of profit, $19^{\text {th }}$-century landlords cleared vast areas of forests to compensate for the loss of their previously owned lands. Furthermore, farmers exploited the remaining woodlands in search of tillage and grazing. When state forestry began replanting trees in 1903, only 69,000 hectares of Ireland's ancient and long-established forests were left, i.e. 1 to $1.5 \%$ of the total land area ${ }^{10}$.

State forestry stopped during the decades that led to the independence of Ireland from Britain. The newly independent state had other priorities on the agenda and reforestation disappeared in the background for some time. The increased demand for fuel and timber during World War I had led to a further reduction of Ireland's forest, and World War II also hindered state afforestation to a considerable extent until the Forestry Act of 1946, which accelerated the process of planting trees by up to 10,000 acres per annum. Furthermore, Ireland's entry in the European Economic Community (now the European Union) in 1973 encouraged afforestation through the privatisation of Ireland's forestry ${ }^{11}$. The European funds, including European Commission grants, helped "eliminating the

8. Eoin Neeson, "Woodland in History and Culture", p. 146.

9. Ibid.

10. Forest Service Department of Agriculture, Fisheries and Food, "Irish Forests - A Brief History", 2008, p. 3, available at: https://www.agriculture.gov.ie/media/migration/forestry/forestservicegeneralinformation/abouttheforestservice/IrishForestryAbriefhistory200810.pdf.

11. Ibid. 
sheep / tree conflict" among the farmers who had joined the reforestation scheme to plant trees in marginal farmlands. According to Neeson, "by 1979 Ireland had the largest and most rapidly expanding forest area per capita in Europe" ${ }^{12}$. Yet this acceleration was to be hindered once again as the country entered a new phase of economic prosperity during the Celtic Tiger period. Among other factors, the growth of urban sprawl led to an increasing demand for building roads that connected the countryside to the cities, which at times required vast clearance of the wooded regions. The popularity of Ireland as a tourist destination since the last decades of the $20^{\text {th }}$ century has also had a double-sided impact on the landscape. While cultural tourism has led to the preservation of certain areas such as Lough Gill in Co. Sligo or Coole Park in Galway, the increasing human interference with the landscape as a result of insufficient management, frequent visits, road construction, traffic, and pollution has had adverse effects on the environment.

Afforestation, the creation of new forests, is still at the top of Ireland's environmental agenda, targeting 1.2 million hectares to be covered by 2030 , i.e. $17 \%$ of the total land use ${ }^{13}$. Despite the continuing process of reviving Ireland's woodlands during the last century, less than $11 \%$ of Ireland's total land area is under forest cover today, leaving the Republic of Ireland at the lower end of the spectrum compared to the European average of $35.5 \%{ }^{14}$. Afforestation is now subject to strict environmental regulations due to biodiversity considerations. Planting the wrong species of trees or cultivating the wrong area would endanger the balance of the ecosystem, which would in turn lead to the extinction of more vulnerable species and the multiplication of others. The European Union-funded schemes to stop further agricultural land use by planting trees in marginal farmlands during the 1980s is one instance that caused a serious threat to bogland biodiversity. Instead of planting on marginal farmlands, the farmers who were given a grant to avoid further land use planted large areas of peat bogs with coniferous evergreen trees such as pine or spruce. The non-native species of Sitka spruce, Norway spruce, Lodgepole pine and Japanese larch make up a total of $60 \%$ of Ireland's forest area compared to an average of $25 \%$ cover by native species like oak, with a growth period of 120 to 150 years $^{15}$. Sitka spruce, which takes about 35 to 55 years to mature, is considered a dominant and renewable source of timber in Ireland despite its lower wood quality as a result of fast growth. On a cultural level, conifers lack the symbolic significance of oaks as emblems of nationhood and spirituality in Ireland and might as well carry "further political and ideological discourses" as in the case of the British dislike of conifers mentioned by Owain Jones ${ }^{16}$.

12. Eoin Neeson, "Woodland in History and Culture", p. 154.

13. Richard O'Hanlon, "Forestry in Ireland: The Reforestation of a Deforested Country", The Forestry Source, June 2012, p. 7.

14. Environmental Protection Agency, Ireland's Environment - An Assessment, Wexford, EPA, 2016, p. 110.

15. Richard O'Hanlon, "Forestry in Ireland...", p. 7.

16. Owain Jones, "Materiality and Identity - Forests, Trees and Senses of Belonging", in New Perspectives on People and Forests, p. 168. 
Having briefly covered the major incidents that led to the deforestation of Ireland, the rest of this essay focuses on the arrival of colonisers and the advent of Christianity as two major events that altered not only the actual shape and form of the landscape, but also changed people's understanding of their surrounding environment and consequently their relationship with it.

\section{Deforested landscapes - the arrival of colonisers}

The constant arrival of the neighbouring tribes and countries and the turbulent history of conquests and exploitations alongside periods of climate change and natural disaster modified the Irish environment in line with Irish culture. From the arrival of the first Christian missionaries to the Norman Conquest of Ireland and from the introduction of feudalism to the later British rule, the land appears to have been the first target of transformation in Ireland. The anonymous writer of "Ireland's Lost Glory" in Birds and All Nature (1900) refers to "the gradual rise of English supremacy in the land" as the most important factor that led to the destruction of Ireland's forests. The English landlords destroyed the woodlands "to increase the amount of arable land, to deprive the natives of shelter, to provide fuel, and to open out the country for military purposes". The writer further refers to the increasing value of timber and the continual destruction of the wooded landscape from the $17^{\text {th }}$ century to the $19^{\text {th }}$, leaving Ireland with only one eightieth of its forested landscape in $1900^{17}$.

At first glance, economic gain seems to be the primary motivation behind the exploitation of forests as well as the cultivation of land and the building of towns. Unlike the native Gaels who did not show much interest in landscaping and farming, the Norman and English settlers had an eye for the hidden profit in the development of an agricultural system as well as using Ireland's dense forests in the form of a timber reservoir. In 1183, Gerald of Wales, who had travelled to Ireland "partly to join the Norman Conquest, partly to see and explore the country" ${ }^{18}$, found the Irish lack of interest in farming and husbandry a sign of barbarity. In the tenth chapter of Topographia Hibernica (1187) he describes the character, customs, and habits of the Irish people as barbarous and slothful:

The Irish are a rude people, subsisting on the produce of their cattle only, and living themselves like beasts - a people that has not yet departed from the primitive habits of pastoral life. [...] their pastures are short of herbage; cultivation is very rare, and there is scarcely any land sown. [...] The whole habits of the people are contrary to agricultural pursuits ${ }^{19}$.

17. N.A., "Ireland's Lost Glory", Birds and All Nature, vol. 7, no. 4, April 1900, p. 188.

18. Annette Jocelyn Otway-Ruthven, A History of Medieval Ireland, London, E. Benn, 1968, p. 1.

19. Gerald of Wales, The Topography of Ireland, Thomas Wright (ed.), Thomas Forester (trad.), Cambridge, In parentheses, 2000, p. 70. 
Dependent on fishing, gathering, hunting, and keeping cattle for the most part, the Gaelic civilisation before the Conquest was automatically considered inferior by the Normans and later on by the English, whose comparatively developed system of agriculture had enabled them to draw benefit from the land. For Gerald of Wales, who described the movement from "the forest to the field, from the field to the town" as a natural course from barbarity to civilisation ${ }^{20}$, the Irish way of life and customs were indeed a sign of incivility and lack of industry. Interestingly, it was not the uncultivated land per se that was subject to negative portrayal; more often than not, the description of the natives' appearance matched the hostile description of their surrounding landscape as "truly barbarous":

This people, then, is truly barbarous, being not only barbarous in their dress, but suffering their hair and beard (barbis) to grow enormously in an uncouth manner [...] indeed all their habits are barbarism. [Barbarism] sticks to them like a second nature ${ }^{21}$.

The derogatory portrayal of the Irish people became a common reference in the later colonial period, when the English found the colonised "the perfect foil to set off their virtues" ${ }^{22}$. Edmund Spenser's description of Irish people in A Veue of the Present State of Ireland (1596) resembles that of Gerald of Wales in attributing characteristics such as wildness, barbarity, sloth, and disorder to the native inhabitants. In a dialogue between the English-based interlocutors Eudoxus and Irenius, the latter, who has recently returned from a recent trip to Ireland and appears to be an expert on Irish matters, explains the native laws, religion, and customs as why the "goodly and commodious [...] soyle" of Ireland had not turned "to good uses, and reducing that salvage nation to better goverment and civillity" ${ }^{23}$. The term salvage (obsolete for savage) is a derivative of sylva, Latin for wood, which further explains the association of the natives with their wooded landscape from a negative perspective. What is seen in both narratives is a colonial point of view that ultimately justifies the exploitation of the neighbouring land. Like Gerald of Wales, Spenser points to the agricultural potential of the Irish soil, yet he goes a step further by asserting his colonial perspective on subjugating the people. Cultivating the land was not only to put the soil to "good use", but to bring the so-called "savage nation" under control and civilise them. While describing the local Brehon laws to Eudoxus and explaining why the English rule had not yet tamed the natives, Irenius reduces the Irish people to animals left on their own, in need of a bridle ${ }^{24}$.

20. Ibid., p. 70 .

21. Ibid.

22. Declan Kiberd, Inventing Ireland: The Literature of the Modern Nation, London, Vintage, 1996, p. 9.

23. Edmund Spenser, A Veue of the Present State of Ireland [1596], Risa S. Bear (ed.), Renascence Editions - Oregon University, 1997, p. 2 (HTML version: http://www.luminarium.org/renascenceeditions/veue1.html).

24. Ibid., p. 5. 
The colonial narrative clearly functions on a dichotomous axis where the colonised are stigmatised as wild, barbarous, and uncultivated; in one word, as other. According to Oona Frawley, aligning "the uncultivated state that the Irish were believed to live in" with "the uncultivated state of the land" implied that taming the landscape would result in taming the people ${ }^{25}$. Hence, the notoriety of the bogs and woodlands was not only a result of the hidden military threat from the Irish; rather the negative attitude towards wilderness and the association of the inhabitants with the wild landscape of their surroundings justified a reform policy to tame the landscape. In the words of William Cronon, the negative attitude towards a landscape is prerequisite to transforming it: "[...] the most basic requirement of [exploiting the land] is that the earlier form of that landscape must either be neutral or negative in value. It must deserve to be transformed" 26 .

Viewed from an ecocritical perspective, the colonised / coloniser binary also reinforces the negative attitude towards nature in the nature / culture dichotomy, justifying the modification and transformation of the physical environment. While referring to the rather unsuccessful project of subjugating the natives under the practice of English laws under Henry VIII and a further suppression of the Irish people during the reign of the "Faerie Queene" - Queen Elizabeth I - Spenser's derogatory portrayal of the Irish system of law, religion, and customs can be studied under the English superior stance not only towards the Irish people but also towards nature. Man as the master of the universe, placed at the uppermost level in the Great Chain of Being - the fruit of Christian and Scholastic philosophies - was still a popular ideology during the Renaissance. This antagonistic view turned into physicophobia, the "alienated, hostile reaction to the natural world" 27 , which the likes of Descartes and Hobbes promoted during the Enlightenment.

While the negative attitude towards the landscape was a key strategy for transforming it, the potential economic benefit of the Irish soil reinforced the colonial narrative of progress based on cultivation and manipulation of the land. Hence, the density of the woods "was to be deplored but also welcomed": deplored for the fear of the unknown harboured in the Irish wilderness, and welcomed for the potential economic benefit of its soil" ${ }^{28}$, described by Spenser as "good and commodious". Cultivation was to bring the maximum energies of the land to the surface, releasing the hidden profit by taming the wilderness. To refer to the unprecedented felling of the forests during the colonial period in Ireland, either for the purpose of transforming woodlands to agricultural land or for the use of

25. Oona Frawley, Irish Pastoral: Nostalgia and Twentieth-Century Irish Literature, London - Dublin, Irish Academic Press, 2005, p. 26.

26. William Cronon, "A Place for Stories: Nature, History, and Narrative", in Nature and Identity in Cross-Cultural Perspective, Anne Buttimer, Luke Wallin (eds.), Dordrecht - Boston - London, Kluwer Academic Publishers, 1999, p. 209.

27. Roy Jackson, "Overcoming Physicophobia - Forests as Sacred Source of Our Human Origins", in New Perspectives on People and Forests, p. 29.

28. John Wilson Foster, "Encountering Traditions", in Nature in Ireland: A Scientific and Cultural History, p. 26. 
timber, the forests and the entire landscape had turned into a massive "standingreserve" of timber "on call for a further ordering" - what Heidegger calls Bestand" The point of view that reduces the landscape to Bestand stands in sharp contrast with the comparatively less intervening role of early Irish culture, misinterpreted as a lack of civilisation in Norman and English views of Ireland.

The relationship between colonisers and the Irish landscape can be further explained through the Heideggerian notion of Anwesen (presencing), which implies disclosure and "bringing-forth" an entity through unconcealment ${ }^{30}$. The coloniser's disclosure of the landscape, however, can be interpreted as Herausfordern, i.e. challenging or forcing an entity toward "furthering something else" 31 . Rather than "setting-in-order" (presencing) as Heidegger observed in The Question Concerning Technology, Herausfordern "sets upon nature" ${ }^{32}$. Hence it is an expedition in two ways:

It expedites in that it unlocks and exposes. Yet that expediting is always itself directed from the beginning toward furthering something else, i.e., toward driving on to the maximum yield at the minimum expense ${ }^{33}$.

This is what Spenser referred to as making "good use" of the soil in Ireland. Viewing the landscape from a standing-reserve perspective is an ecological hindrance to establishing a land community based on a mutual interaction between humans and the environment, mentioned by Aldo Leopold in A Sand County Almanac (1949) ${ }^{34}$. One can possibly argue that a notion of land ethics or geopiety was present in Irish society before the Norman Conquest. As mentioned earlier, the land was a communally owned property in Brehon laws. The very fact that cutting or destroying the trees was consequent with paying fines is proof of a higher degree of ethics regarding the land community. As such, the linear notion of colonial progress is drastically reversed; the pre-Conquest Irish society would stand at a higher ecological level of progress compared to the colonisers' anthropocentric view of the land as potential profit.

Linked to the notion of land ethics, the human-environment interaction in early Irish culture can be interpreted as $d$ welling. In "Building Dwelling Thinking" (1971), Heidegger pursues the links between dwelling and being through the act of building: "The Old English and High German word for building, buan, means to dwell. This signifies: to remain, to stay in a place" 35 . The German terms for building (Bauen) and neighbour (Nachbar) originate from "buri, büren, beuren,

29. Martin Heidegger, Basic Writings, David Farrell Krell (ed.), London, Routledge, 1993, p. 322.

30. Ibid., p. 317.

31. Ibid., p. 321.

32. Ibid.

33. Ibid.

34. Aldo Leopold, A Sand County Almanac, New York, Oxford University Press, 1949.

35. Martin Heidegger, "Building Dwelling Thinking", in Poetry, Language, Thought, Albert Hofstadter (ed. and trans.), New York, Harper \& Row, 1975, p. 146. 
beuron", which signify "dwelling, the abode, the place of dwelling" ${ }^{36}$. Heidegger continues digging up the root of the verb bauen (to build), only to arrive at the verb bin (to be). Therefore, ich bin and $d u$ bist mean "I dwell, you dwell. The way in which you are and I am, the manner in which we humans are on the earth, is Buan, dwelling" ${ }^{37}$. It is from building to being (both derived from the verb "to be") that mankind's relationship with the environment takes the shape of $d$ welling, which in return leads to caring and sparing. Hence, building appears as a means to an end, we build to stay in a place, to dwell. Yet, the fundamental meaning of building as dwelling "has been lost to us" 38 .

The dwelling perspective in the human-environment interaction in early Irish culture can be exemplified in the building of raths, first built in Ireland in the first millennium $\mathrm{AD}^{39}$. Also known as forts or ringforts, raths were circular fortifications, which remained in use until the $12^{\text {th }}$ century ${ }^{40}$. A prototype of an Irish dwelling place in proximity of the natural landscape, raths along with duns, cathairs, and other fortifications were first abandoned or destroyed in the Christian period.

\title{
Despirited forests - the advent of Christianity
}

Among the poems preserved from the early medieval period in Ireland is the trio of fragments from the $6^{\text {th }}$ century $\mathrm{AD}$ with which Thomas Kinsella has opened The New Oxford Book of Irish Verse. The three fragments, read together as a whole, act as a premonition of how the arrival of the other - the Christian missionaries - disrupted the so-called "natural" order of the pagan world, in which the relationship between man and environment could be described as dwelling:

\author{
The rath in front of the oak wood \\ belonged to Bruidge, and Cathal, \\ belonged to Aedh, and Ailill, \\ belonged to Conaing, and Cuilíne \\ and to MaelDúin before them \\ - all kings in their turn. \\ The rath survives, the kings \\ are covered in clay.
}

36. Martin Heidegger, "Building Dwelling Thinking”, p. 147.

37. Ibid.

38. Ibid., p. 146.

39. Bruce Proudfoot, "The Economy of the Irish Rath", Medieval Archaeology, vol. 5, no. 1, 1961, p. 94.

40. Ibid. 
Three rounded flanks I loved

and never will see again:

the flank of Tara, the flank of Tailtiu

and the flank of Aed Mac Ainmirech.

He is coming, Adzed-Head, on the wild-heade sea with cloak hollow-headed and curve-headed staff.

He will chant false religion at a bench facing East and his people will answer "Amen, amen." ${ }^{41}$

The first fragment starts with "The rath in front of the oak wood" that had survived despite the death of the kings who were once owners of the rath. The construction of these dwelling places next to the groves, especially the oak tree which was considered sacred, sanctified the raths and placed man and nature in close proximity, making the words "environment" and "nature" truly interchangeable.

Dwelling was not restricted to raths; rather the entire landscape environing these fortifications was considered a dwelling place by the early inhabitants. In the second fragment, the anonymous poet regrets that he would never see the "Three rounded flanks" of Tara, Tailtiu, and Aed Mac Ainmirech, again. As the fragment cuts short, the reason behind the poet's sense of loss remains unknown. Yet, given the increasing power of Christianity in the $6^{\text {th }}$ century, foreseen in the next fragment, the poet must have anticipated the near destruction of the sites. The sudden announcement of the arrival of the "Adzed-Head" in the first line of the last fragment - "He is coming" - is the harbinger of a sense of doom, arriving from the East. Chanting his "false religion", the man with the "cloak" will soon be taking the first steps in changing the course of history in Ireland by desacralising the groves, bereaving the landscape from its protecting deity (genius loci) and disconnecting the native population from their surrounding environment.

The Christian missionaries also played a fundamental role in the later abolishment of the native traditions of druidry and bardry and the destruction of assembly hills, inauguration sites, raths and forts; i.e. all that was associated with the pagan order of Gaelic society. An early example is the prologue from the $9^{\text {th }}$-century poem, "The Calendar of Oengus", in which the destruction of the ancient dwelling places is hailed by the anonymous poet:

41. The New Oxford Book of Irish Verse, Thomas Kinsella (ed. and trans.), Oxford - New York, Oxford University Press, 1989, p. 3. 
Tara's great palace perished

with the fall of its princes

while great Armagh remains

with all its worthy choirs.

[...]

The Faith has spread

and will last till the Day of Doom

while evil pagans are borne off

and their raths deserted.

[...]

The dún of Emain is vanished,

only its stones remain,

while thronged Gleann Dá Loch

is the monastery of the western world.

[...]

The Pagans' ancient cahirs

not permitted to last long

- they are wastes without worship now

like the place of Lugaid $-{ }^{42}$

The poet portrays the duns, raths, and cahirs deserted and the pagan sites vanished with their kings. He compares the glory and majesty of the newly "crowded shrines" and monasteries to the deserted and destroyed dwelling places and worship sites of the pagan order. Destruction of the sites was equal to dislocating people from their dwelling places next to the forests, therefore distancing man from nature and bringing an end to an age when nature meant environment, a place that environs. Referring to Heidegger's definition of dwelling, Patrick Sheeran argues that "the Irish, apart from the rath-dwellers, have never truly $d$ welt in Ireland any more than the aborigines have $d w e l t$ in Australia" ${ }^{43}$. With the loss of status as $d w e l l i n g$ and the distancing of man from nature, the forests and groves became a periphery, which nevertheless prepared the grounds for the felling of the trees during the colonial period.

Christianity's role in Irish cultural history is double-sided. On the one hand, it prepared the grounds for the further destruction of the forests and the annihilation of earlier customs and traditions; on the other, it led to the preservation of some of the finest examples of Irish oral tradition, such as that of early Irish nature writing, where Christianity remains a "dominant element"; however, as Kinsella notes, the majority of the poems between the $6^{\text {th }}$ and $14^{\text {th }}$ centuries share "a 'pagan' purity of view which gives the lyrics of the early Christian hermits their extraordinary directness

42. The New Oxford Book of Irish Verse, p. 38.

43. Patrick Sheeran, "The Narrative Creation of Place: Yeats and West of Ireland Landscapes", in Nature and Identity in Cross-Cultural Perspective, p. 287. 
and force" 44 "Pangur Bán" and "The Hermit Morbán” are famous examples, where the God of Christianity is seen in nature and the Christian hermits bewail the loss of an earlier connection to nature. Overall, there seems to be little unanimity as to whether it was the Norman Conquest or the English colonisation of Ireland that brought an end to early Irish nature writing. While Christianity desacralised the groves and the Norman Conquest opened the country to foreign exploitation, the decline of Ireland's native traditions, including the genre of nature writing, accelerated under the reign of Tudor monarchs, exemplified in the following stanzas from a late $16^{\text {th }}$-century poem by the Monaghan poet Laoiseach Mac AnBháird:

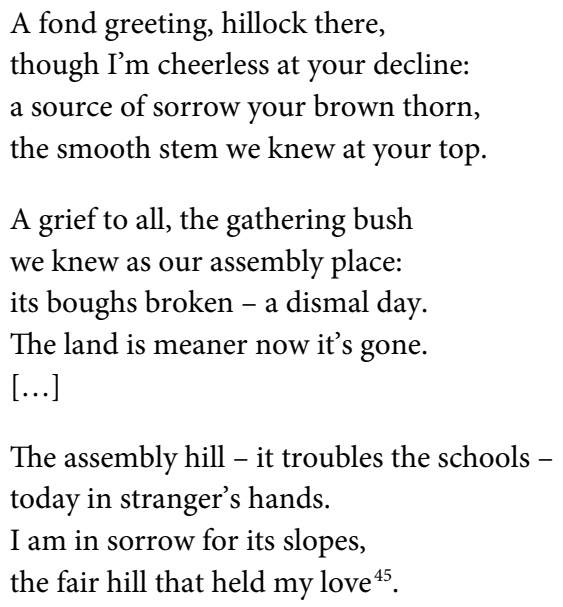

According to the poet, the cutting of the "beloved" tree and the decline of the hillock itself, which had been an inauguration site, had happened in the hands of the "stranger" - the English - who were also responsible for the decline of the bardic schools. By the end of the $16^{\text {th }}$ century bardic poetry was on the wane as the continuous state of war and conflict in Ireland resulted in the banishment of the earls from their native lands, which put an end to the Irish patronage system. The final blow was the Flight of the Northern Earls, Tyrone and Tyrconnell, in 1607, which led to the plantation of Ulster and the rising of 1641. The story of Christianity in Ireland is no less complicated than the history of colonisation and its impact on the environment. Regardless of its subtler effect, Christianity's role in the history of deforestation in Ireland was rather fundamental. By devaluing the landscape, revered by the Irish, the Christian missionaries set the grounds for the expedition and exploitation of the Irish landscape at the hands of the Norman and English colonisers. In other words, depriving the land of its former status as $d$ welling, Christianity brought about the earliest form of cultural mutation in Celtic Ireland, i.e. desacralisation of the landscape.

44. Thomas Kinsella, "Introduction", in The New Oxford Book of Irish Verse, p. xxiii.

45. Laoiseach Mac AnBháird, "A Fond Greeting, Hillock There", in The New Oxford Book of Irish Verse, p. 149-150. 


\section{Conclusion}

The history of human civilisation is often synonymous with the history of deforestation and Ireland is no exception in this case. Deforestation is a long and continuous narrative in Ireland, a narrative that links the colonisation of the land to the colonisation of man. As Eoin Neeson concludes in his study of "Woodland in History and Culture", the history of deforestation covers a "full circle, from a country very largely covered by natural woodland, through one virtually denuded of tree cover, to one in which virtually all woodlands are cultivated as a crop and in which forestry is tree farming" ${ }^{46}$. Today, about half of the Irish forests are in private ownership and less than thirty years of age. Besides, the Republic of Ireland is still considered one of the largest exporters of wood to the United Kingdom ${ }^{47}$.

The growing interest in Irish forestry as in many parts of the world falls back on multiple incentives among which economic gain seems to overshadow environmental concerns. Nowadays, forestry is considered a growing industry in Ireland with a total economic value of $€ 2.3$ billion in 2012, equivalent to $€ 1,096.5$ million in terms of GVA (Gross Value Added). Moreover, the forestry sector has been a source of employment, especially in rural areas while forest outdoor recreational areas have also been contributing to the Irish economy significantly ${ }^{48}$. According to the latest Forest Statistics annual report published by the Department of Agriculture, Food, and the Marine in 2019, Ireland still ranks among the least forested regions in Europe with an average of $10.9 \%$ in 2015 . This is while the European and Worldwide forest cover averages stand at $33.5 \%$ and $30.6 \%$, respectively ${ }^{49}$.

Marjan SHokouнi

The University of Tokyo

46. Eoin Neeson, "Woodland in History and Culture", p. 155.

47. Department of Agriculture, Food, and the Marine, Forest Statistics - Ireland 2019, Dublin, DAFM, 2019, p. 9, 41, available at: https://www.agriculture.gov.ie/media/migration/forestry/ forestservicegeneralinformation/ForestStatisticsIreland280519.pdf.

48. Ibid., p. 54.

49. Ibid., p. 73. 